\title{
H.-K. Rönblom - mellan realism och parodi
}

\section{Ulf Carlsson}

När tidningsmannen Hans-Kristian Rönblom publicerade sin första deckare, Död bland de döda, 1954, var han redan 53 år gammal. Bakom sig hade han en doktorsavhandling i statsvetenskap och en rad uppdrag på liberala tidningar, senast på Aftonbladet där han vid denna tid var politisk redaktör. Hans debutroman bemöttes genomgående med lovord av kritikerna, inte minst för dess stilistiska värden. ${ }^{1}$ Rönblom skulle hinna med ytterligare nio kriminalromaner före sin död 1965: Höstvind och djupa vatten, 1955, Skratta, Pajazzo, 1956, Döden i grytan, 1957, Tala om rep, 1958, Senatorn kommer tillbaka, 1959, Krans åt den sköna, 1960, Död men obegråten, 1961, Bok över obefintliga, 1962, och Mannen som höll sig undan, 1964. Min artikel berör samtliga dessa böcker men uppmärksammar främst Skratta, Pajazzo, där den spänning mellan realism och parodi jag ser som kännetecknande för Rönbloms hela författarskap är särskilt accentuerad.

Pusseldeckaren är fortfarande det helt dominerande mönstret i efterkrigstidens svenska kriminalroman. Samtidigt modifieras modellen i dess renodlade skick av de ledande företrädarna, hos Stieg Trenter genom att den komplicerade gåtan kombineras med stämningsrik storstadsskildring, hos Maria Lang genom att genrens tidigare ointresse för psykologi vänds till freudianskt färgade inblickar i brottslingens själsliv, hos Vic Suneson genom en inspiration från amerikansk film noir och den framväxande polisromanen.

I ett internationellt perspektiv blir förnyelsen än tydligare. Redan under mellankrigstiden utvecklades i USA den hårdkokta deckaren med Raymond Chandler som stilbildare. Dess samhällskritik och frekventa våldsinslag kontrasterade starkt mot pusseldeckarens snäva sociala horisont och skygghet för allt som kunde uppröra läsaren. Georges Simenon skildrade via sin kommissarie Maigret en polisiär vardaglighet där rutinarbete och kunskap om människor och miljöer spelade större roll än utredarens genialitet. Efter kriget framträder sedan en rad författare som på olika vis exemplifierar den trend Julian Symons har beskrivit som "förändringen mot en realistisk eller t.o.m. brutal roman om verklig kriminalitet, romanen som använder brottstemat som en metod att undersöka och beskriva människans psykologi”. ${ }^{2}$

Också H.-K. Rönbloms deckare kan uppfattas i ljuset av Symons analys av tilltagande realism, i detta fall med tonvikt på samhällsbilden. Romanerna har betecknats dels som "ett slags sociologiskt studium och dokumenterande av ett Sverige i förvandling under 50-talet", dels som att de "arbetar vidare på den inventering av det svenska samhället som tiotalisterna inledde några decennier tidigare". ${ }^{3}$ Citaten signalerar en närhet till realismen som litterär tradition och det intresse för bred samhällsskildring som återfinns hos tidigare svenska författare som t.ex. Hjalmar Bergman och Birger Sjöberg. Samtidigt är "realism" ett mångtydigt och problematiskt begrepp, som inte minst kriminalromanens teoretiker har undvikit. En del av min artikel diskuterar dessa frågor och i vilka avseenden Rönbloms romaner kan beskrivas som realistiska.

1 Lars Wendelius, Deckarförfattaren H.-K. Rönblom. En profilteckning, Uppsala universitet 1995, s. 14f.

2 Julian Symons, Lilla mordboken. Från detektivhistoria till kriminalroman - en historik (Bloody Murder, 1972), övers. Sune Karlsson, Berghs förlag 1979, s. 185. Symons framhäver bl.a. Patricia Highsmith, John Bingham, Ross Macdonald och Friedrich Dürrenmatt. Han skrev dessutom själv flera romaner med en tydlig ambition att skildra samtida verklighet.

3 Karl Arne Blom, "Appendix" i Symons, Lilla mordboken, s. 314; Wendelius, Deckarförfattaren H.-K. Rönblom, s. 20. 
Mot strävan att förena pusseldeckaren med en skildring av det samtida Sverige står emellertid hos Rönblom en tendens till parodi av genren. Ett andra avsnitt av artikeln behandlar sådana inslag, som dessutom ofta får en metafiktionell karaktär och kastar ett ironiskt ljus över den egna framställningen. Avsnittet beskriver också Rönbloms relation till Dorothy L. Sayers, den föregångare som uppenbart varit den viktigaste inspirationen för honom och som likaledes försåg sina romaner med parodi av lekfull eller ambivalent art. Jag diskuterar här även om författare som Sayers och Rönblom kan sägas sikta mot en höglitterär nivå, en fråga som återkommit i teoretiska texter kring genren.

Artikeln avslutas sedan med ett avsnitt kring de ideologiska spänningar jag tycker mig se i Rönbloms romaner. Tilltron till den enskildes beslutsamhet och rättvisekänsla bryts där emot determinism, en upplevelse av att människan i själva verket är ofri och styrd av de starkare krafter som ryms framförallt i samhällets prägling.

Två tidigare studier måste framhållas. Lars Wendelius' Deckarförfattaren H.-K. Rönblom. En profilteckning från 1995 behandlar en rad viktiga aspekter, inte minst hur Rönblom hanterar mordgåtan som centralt motiv. Wendelius' arbete har lagt grunden till all efterföljande forskning i ämnet. Sara Kärrholms Konsten att lägga pussel. Deckaren och besvärjandet av ondskan i folkhemmet, 2005, innehåller bl.a. en analys av Senatorn kommer tillbaka, där Kärrholm menar att Rönblom genom sin motbild av idyll, familj och kollektiv förebådade den samhällskritiska kriminalroman som skulle slå igenom i Sverige med Sjöwall-Wahlöö på 60-talet.

Skratta, Pajazzo berättar om hur ägarna av Komosse glasbruk, de tre syskonen Lesser, samlas för att avgöra brukets framtid. Direktören, Mackenzie Lesser, vill inför växande ekonomiska svårigheter inrikta tillverkningen mot enkelt bruksglas och dessutom sälja familjens stora bruksvilla till staten och dess vård av ungdomsbrottslingar. Systern, officersänkan Margaret, motsätter sig planerna, främst av pietet mot föräldrarna, brukets grundare. Den yngre brodern, operasångaren Augustin, ställer sig också negativ då han upplever sig kränkt av att staten i förhandlingarna skall företrädas av byrådirektören Viran Albinsson, arbetardotter från orten och trettio år tidigare Augustins fästmö under en period.

Vid det första mötet mellan Viran och syskonen faller Augustin död ner sedan han avsjungit sitt gamla paradnummer, "Skratta, Pajazzo", och druckit ett glas sherry. Läkarna misstänker en allergisk chock, orsakad av den vitamininjektion han gett sig själv strax dessförinnan. Husets betjänt, den gamle Barrman, uppfattar sig emellertid som misstänkt eftersom han serverat sherryn. Han uppsöker därför Paul Kennet, läroverkslärare men också känd som framgångsrik amatördetektiv, vilken tillfälligt vistas i Komosse tillsammans med sin syster Susanne och som nu åtar sig att undersöka fallet.

Kennet träffar under historiens gång glasblåsaren Arklin, som verkar för att bruket istället skall satsa på exklusiv konstglastillverkning och som har skapat en mindre glasskulptur föreställande just Pajazzo. Han träffar också bruksbokhållaren Karolin, Augustins son utom äktenskapet, som hyst förhoppningar om att via en lagändring få sin arvsrätt efter fadern erkänd. Karolin närvarade i villan vid dödsfallet och så också hans något äldre fästmö, Mary, Barrmans systerdotter som arbetar där i köket. Genom Mary får Kennet veta att flaskan med Augustins vitaminlösning försvunnit.

Samtidigt med utredningen fortgår diskussionerna kring bruket, bl.a. vid Viran Albinssons möte med byborna som då visar sin rädsla för den planerade anstalten. Efterhand växer dock en 
medvetenhet om att situationen är ohållbar. Företagets advokat, Ferenberg, anländer och hjälper fram en uppgörelse, som beseglas då de starkaste krafterna inom arbetarkollektivet uppvaktar Mackenzie med en morgontida blåskonsert på dennes födelsedag. Man enas om omläggningen till pressglas och bruksvillans försäljning mot att orten får pengar till en samlingslokal. Karolin garanteras den tjänst som bruksförvaltare han eftersträvat.

Kennet, som inte avbrutit sin egen undersökning trots ägarnas hotelser, kan till sist avslöja sanningen bakom Augustins död. Mary har preparerat dennes vitaminlösning med stoff som utlöst en delvis hemlighållen allergi mot hästar. Av fruktan för att bli övergiven av sin yngre och ståndsmedvetne fästman har hon mördat för att förekomma den förändring av arvslagen som Karolin inväntar och som skulle innebära hans sociala upphöjelse. Ironiskt nog visar sig Karolin ha missförstått och överskattat vad lagändringen skulle medföra för hans del.

Handlingen framskrider i ett relativt lågt tempo, utan de högdramatiska inslag som är vanliga hos t.ex. Trenter och Lang. Öppet våld förekommer egentligen bara i en av Rönbloms romaner, Död men obegråten, i ringa grad i ytterligare någon. ${ }^{4}$ Däremot används ofta s.k. cliffhangers som avslutning på kapitlen, men sådana visar sig antingen högst begränsade till sitt spänningsinnehåll eller kan t.o.m. följas av en ironisk antiklimax. Istället får framställningen liv genom kombinationen av en framträdande berättarstämma och en utpräglat scenisk framställning, där personerna konfronteras med varandra i komiska eller psykologiskt laddade möten, där nya entréer ger rörelse och omväxling, och där dialogen ofta innehåller dråpliga poänger. Romanens inledningskapitel ger prov på Rönbloms teknik. Det har titeln "Prolog i lantlig butik” och kan sägas följa en gammal dramatisk konvention, att orientera publiken om utgångsläget via samtal mellan ett antal bifigurer, gärna tjänstefolk. Här skapas omedelbart en spänning, då betjänten Barrman stiger in i handelsboden och menigheten där avvaktar vad hans besök kan säga om tillståndet i bruksvillan och indirekt om glasbrukets framtid. Den förtegne Barrman tillmötesgår inte ortsbornas nyfikenhet, men däremot kommer varje inköp han gör att tolkas som ett tecken, så t.ex. då han begär två burkar soppsparris:

Det var något $\mathrm{i}$ hans ton som kom de andra att lystra. Till och med den åttaåriga flickan slutade upp att suga på sin karamell.

- Gud i höjden, sade packhusfrun, två burkar soppsparris! Det räcker till bra mycket soppa, det.

- En hade räckt till för direktörn och herr Karolin, sade kontoristen. Ni skall se att alla syskonen kommer hit till födelsedagskalaset. (s. 15f)

Scenen återges med diverse komiska iakttagelser - "- Råckefårt, sade handlanden på sin flytande franska och svängde med armen" (s. 14) - och kompletteras med omfattande exkurser, där berättaren introducerar de olika figurerna, gärna med raska sammanfattningar av deras personlighetsdrag och ställning i samhället, men också beskriver ortens mentala klimat och den sociala hierarki som råder. När Barrman utträtt och lämnat de övriga åt spekulationer kring den stundande måltiden i villan, får istället brorsdottern Mary, även hon med insyn i

maktens boning, göra sin entré och som avslutning på kapitlet ge den gåtfulla upplysningen att en viktig gäst verkligen skall anlända och att det dessutom är fråga om en kvinna.

Berättaren är av det traditionella slag som brukar beskrivas som allvetande och som ogenerat ger insyn i olika figurers tankar och känslor, värderar deras egenskaper, tolkar kollektiva opi-

4 Jag avser Rönblom, Senatorn kommer tillbaka, Vingförlaget 1961, som innehåller ett slagsmål med rasistiska drivkrafter. 
nioner och sammanfattar både historiska perioder och levnadsvillkoren för ett samhälle. Den kan t.o.m. tillåta sig generaliseringar av typen "Som småväxta personer understundom är var herr Karolin benägen att topprida sin omgivning" (s. 47). Det är en berättare, som i hög grad kan synas som ett arv från 1800-talet och vars distans till skeendet skiljer sig från de samtida konkurrenternas: de subjektiva och emotionella röster som förmedlar handlingen hos Trenter och Lang, inlevelsen i oroliga och plågade själstillstånd hos Suneson. Samtidigt finns hos denne rönblomske berättare en förkärlek för mångtydig ironi, för komisk stilbrytning och för hänsyftningar på äldre litteratur som riktar uppmärksamheten mot språket som något mer än enbart ett instrument för stark illusionsverkan. Texten kompliceras på så sätt genom inslag som pekar bortom den tongivande realismen.

\section{2}

Studier av realismen betonar närmast obligatoriskt termens problematiska karaktär. Damian Grant menar t.ex att beteckningen realism "is a prodigy that most people feel they could do well without" och att den innebörd ordet gavs av dess programmatiska förespråkare under 1800-talet inte längre är teoretiskt hållbar. ${ }^{5}$ Pam Morris beskriver termen som "slippery", inte minst därför att den har både en vardagsspråklig och en estetisk användning. ${ }^{6}$ Lars-Olof Åhlberg understryker spänningen mellan å ena sidan den realism som fått ge namn åt en litterär epok, å den andra en "tidlös" realism med enbart vissa drag gemensamma med den som lanserades i mitten av 1800-talet. ${ }^{7}$ Anders Pettersson, som bl.a. utreder hur termen har utnyttjats inom olika språkområden, sammanfattar att dess mångtydighet är "irreducibel" och att olika realismbegrepp ändå bör bibehållas så länge de inte strider mot normalt språkbruk. ${ }^{8}$

Till dessa svårigheter som har att göra med vad man egentligen avser med realism - ett vardagligt verklighetssinne, en historiskt avgränsad konstriktning, eller mera generellt en strävan att avbilda t.ex. människans psykiska eller sociala verklighet - kommer ytterligare andra. Några teoretiker berör frågor av intresse för förhållandet mellan 1800-talsrealismen och den samtidigt framväxande kriminalberättelsen. Jerry Palmer framhäver inte någon sådan relation, då han ser kriminalromanens litterära ursprung i tre andra genrer, "Heroic Romance", "Gothic" och "Police Memoirs and Low-Life Literature". ${ }^{9}$ Philippe Hamon menar att realismens diskurs ständigt skyndar att fylla varje informationsgap för läsaren och därför är helt främmande för intriger som innehåller spänning. Mot denna uppfattning som avgränsar realismen från all litteratur som skapar gåtor eller låter läsaren sväva i ovisshet, står Pam Morris som istället hävdar att det är typiskt för realismens roman att inledningsvis ställa frågor kring figurer och situationer och besvara dem först under läsningens gång. ${ }^{10}$

5 Damian Grant, Realism, Methuan 1970, s. 1, 74.

6 Pam Morris, Realism, Methuan 1970, s. 1, 74.

7 Lars-Olof Åhlberg, Realismbegrepp i litteratur och konst. En idéhistorisk och konstfilosofisk studie, Almquist \& Wiksell International 1988, s. 22.

8 Anders Pettersson, Realism som terminologiskt problem. Några definitioner i modern litteraturvetenskap och deras giltighet, Liber 1975, s. 153

9 Jerry Palmer, Thrillers: Genesis and Structure of a Popular Genre, Edward Arnold 1978.

10 Philippe Hamon, "On the Major Features of Realist Discourse", i Realism, ed. Lilian R. Furst, Longman 1995, s. 180f. Morris, Realism, s.11. Till en del handlar olikheterna om inhemska traditioner, där den engelska realism Morris diskuterar aldrig fick samma utpräglade karaktär som hos t.ex. Flaubert eller Zola. Till en del handlar de om att Hamon vill isolera och framhäva det djupast kännetecknande och särskiljande för perioden, medan Morris istället ser bredden och variationen i realismens repertoar. 
Generellt kan sägas att ett antal författare som betecknats som realister, däribland Balzac och Dickens, i sin strävan efter verklighetsavbildning ändå gav utrymme för romantiska, melodramatiska och spänningsladdade inslag i sina texter. Dessa och flera andra utnyttjade också samtidens kriminalitet som ett framträdande motiv i romanerna. D.A. Miller har i sin The Novel and the Police analyserat de intrikata förbindelserna mellan detektivberättelse och realistisk roman, bl.a. med fokus på Wilkie Collins' The Moonstone och Dickens' Bleak House. ${ }^{11}$

Sådana kriminalromanens teoretiker som Stephen Knight och Dennis Porter är mera intresserade av att bestämma den ideologiska hållning som kännetecknar genren och dess ledande företrädare än av förhållandet till litterära traditioner. "His apparent realist modernism conceals a conservative and elitist position", skriver t.ex. Knight om Raymond Chandler. ${ }^{12}$ En estetisk beteckning som "realist modernism", diffus redan i sig, får här tjäna enbart som maskering för en förment mera djupgående ideologisk karaktär. Porter försöker i och för sig precisera några drag som infogar kriminalberättelsen i realismens tradition:

(...) mainstream detective fiction respects the conventions of the realist tradition. That is to say, it situates its actions in contemporary social reality, limits the types of crime and methods of detection to what passes for rationally plausible, and choses as its characters easily identifiable human or social types. Further, detective stories present themselves to their readers as substitute worlds or mirrors that reflect directly the reality beyond. All traces of their processes of production as texts are effaced in the interest of the illusion. ${ }^{13}$

Analysen siktar till att fånga en minsta gemensam nämnare för genren som helhet snarare än att diskutera hur realismens normer spelat en växlande roll under kriminalromanens historia. Betecknande är också att Porter visserligen lyfter fram inslag av realism hos sådana författare som Chandler och Simenon, men samtidigt framförallt inriktar sig på stilanalys. Så t.ex. hävdar Porter att den litterära realism som Chandler och dennes föregångare Dashiell Hammett exemplifierar handlar om "stylization" snarare än om att återge verkligheten på ett exaktare sätt än t.ex. Agatha Christie. ${ }^{14}$

Både Knight och Porter ter sig i varierande grad präglade av en poststrukturalistisk misstro mot språkets möjligheter till verklighetsrepresentation och en inriktning på realismen främst som retorisk teknik. ${ }^{15}$ Man kan mot en sådan syn ställa t.ex. Pam Morris' uppfattning om realism som "any writing that is based upon an implicit or explicit assumption that it is possible to communicate about a reality beyond the writing". ${ }^{16}$ Morris är på så sätt mera i linje med den beskrivning av realismen som man återfinner hos äldre teoretiker. Så har t.ex. Erich Auerbach betonat två avgörande kännetecken för den moderna realism som formades under 1800-talet: dels "verkliga vardagshändelser i ett lågt samhällsskikt", dels att dessa händelser är "djupt förankrade i en bestämd historisk-samtida epok". ${ }^{17}$ Raymond Williams talar om en inriktning mot "ordinary, contemporary, everyday reality" och ser som utmärkande för just 1800-talets realism

11 D. A. Miller, The Novel and the Police, University of California Press 1988.

12 Stephen Knight, Form and Ideology in Crime Fiction, McMillan 1980, s. 136

13 Dennis Porter, The Pursuit of Crime. Art and Ideology in Detective Fiction, Yale University Press 1981, s. 115.

14 Porter, The Pursuit of Crime, s. 131.

15 Knight hänvisar till framförallt Roland Barthes och Pierre Macherey i Form and Ideology, s. 4f; Porter till Roland Barthes i The Pursuit of Crime, s. 131.

16 Morris, Realism, s. 6.

17 Erich Auerbach, Mimesis. Verklighetsframställningen i den västerländska litteraturern (Mimesis. Dargestelle Wirklichkeit in der abendländischen Literatur, 1946), övers. Ulrika Wallenström, Bonniers 1998, s. 513, $519,545$. 
"a particular apprehension of a relation between individuals and society". ${ }^{18}$ René Wellek framhäver "the depiction of contemporary manners" och "the interest of social typology". ${ }^{19}$ Morris i sin tur menar att realismens inriktning mot "historical particularity" är ett oeftergivligt krav. ${ }^{20}$

Då jag i fortsättningen diskuterar realismen i H.-K. Rönbloms texter avser jag den uppfattning om begreppet som man kan utläsa i just dessa studier: vardagligheten, inriktningen mot samtiden och dess seder, viljan att studera individen i relation till samhället och infogad i ett historiskt perspektiv. Rönblom kan i hög grad beskrivas som en arvtagare till 1800-talsrealismen och dess förvaltare i svenskt tio- och tjugotal.

Så gott som genomgående dras Rönblom till det glanslöst ordinära. Han skärskådar livsvillkor och seder framförallt i de små samhällena eller medelstora städerna i modernitetens periferi eller bakvatten, miljöer som saknar både det hektiska storstadstempot hos Trenter och Suneson och de romantiska idylldragen hos Lang. Tonen anslås redan då Paul Kennet i inledningen till debutromanen Död bland de döda anländer till det nedgångna landsbygdspensionat, där berättelsen utspelar sig:

Själva huset var stort, gammaldags och till nödtorft underhållet. Den svaga och disiga kvällsdagern dolde barmhärtigt det mesta av skavankerna. Ytterväggarna var såriga av frost och fukt; deras ursprungliga färg var grå som dimman omkring. Mitt på fasaden ledde några höga franska fönster ut mot en terrass med vissnande perenna växter. Åsynen av fönstren anknöt omedelbart till tanken på golvdrag i rummet innanför dem. ${ }^{21}$

Romanerna skildrar miniatyrvärldar, präglade inte bara av de traditioner som lever vidare i efterkrigstidens Sverige utan också av de konflikter som uppstår med den pågående samhällsomvandlingen. Det är på en gång frikyrkans, godtemplarlogernas och fackföreningsrörelsens folkhem och en arena där politiska och ekonomiska intressenter kan mötas i mer eller mindre öppen kraftmätning eller ingå oheliga allianser. I flera romaner återkommer Rönblom till oegentligheter som uppdagas under handlingens gång och som har sin rot i hur de lokala eliterna hanterat medel som ställts till deras förfogande. Med morden accentueras sedan ytterligare samtidens sociala friktioner.

Aktörerna beskrivs också mot en samhällelig och historisk bakgrund som tecknas mer eller mindre utförligt. Tydligast framgår detta i Skratta, Pajazzo, där Komosses historia alltsedan grundandet vid 1800-talets mitt sammanfattas tidigt i romanen och på inte mindre än tre sidor. Utredningen av mordfallet löper sedan parallellt med försöken att lösa brukets ekonomiska kris. I flera andra böcker ger berättaren i de första kapitlen överblickar av glesbygdssamhällenas sociala struktur och deras ställning i den fortskridande utvecklingen. En roman med den betecknande titeln Bok över obefintliga blir en studie av en by dömd till undergång i moderniseringsprocessen. I Mannen som höll sig undan har å andra sidan kriminalgåtan ett nära samband med de spekulationsmöjligheter som öppnar sig med den snabba tillväxten i en expansiv mindre tätort.

Också gärningsmännen måste oftast förstås mot denna bakgrund. Man kan förvisso även hos Rönblom finna mördare drivna av svartsjuka eller ren vinningslystnad, pusseldeckarens båda klichémotiv. Det finns då hos författaren en uppenbar strävan att nyansera bilden av förövarna som skiljer honom från de flesta av genrens utövare. Mest utmärkande för Rönblom är emel-

18 Raymond Williams, The Long Revolution (1961), Broadview, 2001 s. 300, 305.

19 Citerad i Åhlberg, Realismbegrepp i litteratur och konst, s. 49.

20 Morris, Realism, s. 94.

21 H.-K. Rönblom, Död bland de döda, Vingförlaget 1956, s. 5. 
lertid att brottslingarna i flera av romanerna slår till då de upplever sin samhällsposition och sitt rykte som hotade. Mördarna i Höstvind och djupa vatten, Döden i grytan, Tala om rep och Död men obegråten har alla bakom sig grova misstag eller enskilda synder som skulle punktera deras karriärer om sanningen kom i dagen. Den unge brottslingen i Senatorn kommer tillbaka och den svartsjuka hustrun i Krans åt den sköna mördar också för att dölja tidigare felsteg. De exemplifierar på så sätt den känslighet för omgivningens dom och den svaghet för den egna prestigen som blir som tydligast i de små samhällen där alla känner varandra. Människorna framstår hos Rönblom som formade framförallt av det sociala spelet, av ansträngningen att bevara en fasad mot omvärlden. Däremot står ingenstans att finna den djupa märkningen av traumatiska barndomsupplevelser som t.ex. Maria Lang återkommer till.

Karolin i Skratta, Pajazzo blir ett belysande exempel. Han sägs visserligen vara bitter över den oförrätt som tillfogats honom då han ställts utanför familjen Lesser, men samtidigt noterar Paul Kennet hans likhet med de självmedvetna syskonen (s. 107, 110). Egoistisk, streberaktig och med ett ständigt behov att markera sin auktoritet, företräder också han den karaktärstyp Rönblom så gärna lyfter fram. Icke desto mindre är han oskyldig till mordet - som heller inte var till hans fördel. Den dödande lösningen har istället tillretts av Mary Barrman, som fruktar att bli åsidosatt om hennes älskare flyttas upp i samhällshierarkin. "En förvaltare, fortsatte Mary, kan inte vara gift med - med vem som helst. Han säger att han måste tänka på sin ställning" (s. 160). Motivet kan synas långsökt, men det illustrerar väl hur det kvardröjande klassamhället med dess skrankor ofta gör sig påmint hos Rönblom. Ingenstans får det en bredare belysning än just i Skratta, Pajazzo, där Paul Kennet i den traditionsbundna bruksmiljön möter ett helt spektrum av typer präglade av sin sociala position och ofta iakttagna med karikatyrens komik och känsla för språkliga variationer. Här finns ägarfamiljen med den sluge och maktfullkomlige Mackenzie och hans högfärdiga syster, här finns betjänten Barrman, formad av årtionden av diskret uppassning, och dessutom en dråpligt pratsam värdshusvärd, en myndig skollärare, en beställsam handlande, en smed, grovt folklig i sitt uttryckssätt, och diverse andra glasbruksarbetare och deras familjer. Alla kommer till tals inom texten men de förblir med få undantag namnlösa och därigenom än starkare identifierade med sin yrkesroll.

Här finns också Viran Albinsson, en gång fattigflicka på orten men nu socialdemokratisk byråchef med möjlighet att avgöra brukets öde. Viran representerar samhällets nya elit, den som i romanens slutskede och med den lokala arbetarrörelsens stöd finner en kompromiss med ägarfamiljen. Texten blir ett åskådningsexempel både på samtidens närmande mellan stat och kapital och på hur maktspel tillgår olika intressenter emellan. "Har direktören blivit socialist?" frågar den överraskade Arklin då Mackenzie Lesser med välanpassad retorik tillkännager att företaget "måste handla i samförstånd med det allmänna" (s. 40). Rönblom träder in i en realistisk tradition som kan spåras tillbaka till Balzac, Hjalmar Bergman och andra som skildrat de högre samhällsklassernas manövrer för egen vinning. I porträttet av Viran balanseras i övrigt iakttagelser som understryker hur även hon präglats av sin roll - cigarettetuiet i sköldpadd, yrkeskvinnans grå dräkt, bristen på varje spår av "moderlighet" - mot hennes sympatiska brist på revanschism gentemot den familj som en gång avbröt förhållandet till Augustin (s. 42f, 198). I Rönbloms värld, där personlighetsdrag gärna blir övertydligt accentuerade, är denna moderna kvinna till sist märkligt undflyende, som om författarens ironiska blick ännu inte bestämt sig för hur hon skall kategoriseras.

Annorlunda då med Virans manliga motsvarighet i Höstvind och djupa vatten, riksdagsmannen Axel Ehlevik - född Olsson - som under karriärens gång inte bara bytt namn utan också 
undanröjt ett vittne till den bussolycka han en gång orsakat genom sitt slarv. Ehlevik beskrivs som en människa "som kanske inte alltid var så nogräknad när det gällde hans egen framfärd men som höll desto mera strängt på formerna när det gällde andras". ${ }^{22}$ Att han fungerar som symptom på en mera omfattande sjuka tydliggörs då Kennets undersökning sammanflätas med en pågående valrörelse, där Ehleviks aldrig namngivna parti vinner framgång. Efter det självmord som ändar dennes bana blir han dessutom föremål för en respektfull parentation i den nykterhetsloge som har föga intresse att sprida sanningen om sin logebroder. Även denna roman slutar så i ironins tecken.

Till Rönbloms ambition att granska samtidens liv hör också ofta uppsluppna och milt satiriska scener kring olika sociala evenemang. I Död bland de döda handlar det om "offentlig underhållning med dans på godtemplarhuset", en höjdpunkt i ortens annars påvra nöjesutbud och i texten en exkurs med enbart svag anknytning till kriminalgåtan. ${ }^{23}$ Liknande folkhemska festligheter, en logdans och ett midsommarfirande, beskrivs i Senatorn kommer tillbaka och Krans åt den sköna. Skratta, Pajazzo präglas till stor del av kollektiva scener från handelsboden, värdshuset och bykaféet där den lokala opinionen vädras. I avsnittet då ortens fackliga ledare med sin mässingssextett och tidigt i gryningen uppvaktar Mackenzie Lesser på dennes födelsedag, förvaltar sedan Rönblom väl arvet från Bellmans och Birger Sjöbergs komiskt livfulla texter kring liknande konserter. ${ }^{24}$

Rönbloms breda samhällsskildring i den traditionella realismens anda bör naturligtvis kontrasteras mot den renodlade pusseldeckarens begränsade sociala perspektiv och fokus på hårt konstruerade gåtor. Samtidigt lever gåtan vidare även hos Rönblom, där mördaren ständigt är att finna inom en given, mindre krets av misstänkta och där upplösningen gärna dramatiseras och bjuder på överraskande vändningar. Det bör också betonas att mordet - med något undantag - heller inte får någon brutal, tragisk eller upprörande karaktär, utan tonas ner i enlighet med pusseldeckarens konventioner. $\AA$ andra sidan visar Rönblom en tydlig strävan att trivialisera samtliga för genren centrala ingredienser, miljö och gärningsmän men också mordoffer och detektiv.

Notarien Odell som tas av daga medelst en överdos insulin i Död bland de döda framstår som en obetydlig och tråkig människa som ingen tycks ha anledning att mörda. Brottet visar sig i slutänden orsakat av att notarien vunnit en större summa på en penningobligation. ${ }^{25}$ I Höstvind och djupa vatten förlorar även mordmetoden varje spår av raffinemang. Elavläsaren Gerhard Bäck färdas på moped på en bakgata då han kör på en uppspänd ståltråd och spräcker skallen. Undersökningen visar att denna annars anonyma figur blivit "anfäktad av ryktbarhetens demon", d.v.s. drivits av viljan att inträda i det sociala spelet och hotat att avslöja den ovannämnde riksdagsmannen Ehleviks skuld. ${ }^{26}$ Augustin Lesser i Skratta, Pajazzo har under en period av framgång som sångare upplevt just ryktbarhet, men beskrivs i övrigt som svag och obeslutsam i förhållande till de andra syskonen. I likhet med Odell och till skillnad från genrens konventioner kan han heller inte sägas ha orsakat det brott han utsätts för. Det gäller däremot

22 H.-K. Rönblom, Höstvind och djupa vatten, Bra Böcker 1976, s. 16.

23 Rönblom, Död bland de döda, s. 124.

24 Jag tänker i första hand på Birger Sjöberg, "Dansbanan", Fridas bok, Samlade dikter, Bonniers 1954, s. 53ff, som Rönblom t.o.m. citerar i Höstvind och djupa vatten, s. 144. Sjöbergs relation till flera Bellman-texter analyseras i Sten Malmström, "Birger Sjöbergs Dansbanan och Min fordran är ej ringa", Stil och vers i svensk 1900-talspoesi, Norstedts 1971.

25 Rönblom, Död bland de döda, s. 233.

26 Rönblom, Höstvind och djupa vatten, s. 184. 
den förmögne konsthistorikern Krister Ordahl i Död men obegråten, vars hånfulla och manipulativa uppträdande resulterar i en kollektiv avsky bland hans gamla klasskamrater. Romanen, som utspelar sig i storstadsmiljö och med åtskilliga thrillerinslag, är på flera sätt ett undantag i Rönbloms produktion, i lägre grad präglad av hans personliga ton. Greppet att som här låta samtliga misstänkta ha starka motiv för mordet på en tyrannisk personlighet är återkommande i pusseldeckaren. $^{27}$

"...en omkring fyrtioårs herre som bar portfölj. Flyktigt besedd kunde han tänkas vara någon lägre tjänsteman av det slag som tar emot blanketter och ser till att alla prickade rader är ifyllda". Så uppenbarar sig Paul Kennet i Rönbloms fjärde bok, Döden i grytan. ${ }^{28}$ Han sägs i annat sammanhang se ut som "mannen som förlorat sitt paraply. Hans ansikte var menlöst som på ett passfoto". ${ }^{29}$ I flera av romanerna deltar också Kennet i skeendet i lägre grad än vad som kan förväntas av huvudpersonen-detektiven, i Tala om rep i enbart en tredjedel av texten, i Senatorn kommer tillbaka i ungefär hälften. I Skratta, Pajazzo närmast smygs han in i handlingen utan dramatiska åthävor efter 70 sidor, men får därefter en relativt omfattande presentation. Nykteristen, läroverksadjunkten och historikern Kennet påstås här vara i besittning av en "hemlig stridslystnad som ibland överraskade honom själv (---) han kunde snoppa av någon tvärsäker myndighetsperson eller rida spärr mot någon gängse uppfattning” (s. 71). Mot hans yttre färglöshet står en envis och självständig karaktär, som kommer till synes i hans undersökningar. Den angivna drivkraften bakom dessa kan variera - nyfikenhet, sanningslidelse, historikerns dragning till olösta frågor, engagemang för de oskyldigt misstänkta, önskan att rättvisa skall vederfaras den döde. I Skratta, Pajazzo reagerar Kennet starkt mot misstanken att han skulle gått in i brottsfallet utifrån pekuniära motiv (s. 122f). Men han kan samtidigt visa skeptisk distans gentemot sin detektiva gärning, omtala den som antingen "helig mission eller osund förströelse", och efter avslutat uppdrag undra om "det goda man uträttar väger upp allt det onda man ställer till med". ${ }^{30}$ Självprövningen kontrasterar starkt mot den triumferande tonen hos sådana föregångare som Holmes och Poirot.

Hobbydetektiven Paul Kennet, som villigt engagerar sig i och löser de brottsfall han stöter på, är till sist naturligtvis ändå inte någon särskilt sannolik karaktär. Snarare framstår han som ett av flera exempel på hur Rönblom förhandlar mellan å ena sidan realismens samtids- och samhällsskildring, å den andra genrens nedärvda konventioner. Ofta löser Rönblom detta problem genom att ge texterna starka drag av parodi.

\section{3}

Sentida studier av parodin, av Linda Hutcheon, Margaret A. Rose och Simon Dentith, betonar samtliga att termen innefattar inte bara det kritiskt förlöjligande, utan också respekt, lekfullhet eller ambivalens i förhållande till den parodierade texten. "Para" betyder, som Rose framhäver, både "vid sidan av" och "mot". ${ }^{11}$ Denna bredare och skiftande innebörd av begreppet är aktuell

27 Det mest bekanta exemplet är sannolikt Agatha Christies Mordet på Orientexpressen (Murder on the Orient Express, 1934), övers. M. Isberg, Bonniers 1953.

28 H.-K. Rönblom, Döden i grytan, Vingförlaget 1959, s. 15.

29 Rönblom, Höstvind och djupa vatten, s. 16.

30 H.-K. Rönblom, Krans åt den sköna, P.A. Norstedt \& Söner 1960, s. 110; Rönblom, Senatorn kommer tillbaka, s. 224.

31 Linda Hutcheon, A Theory of Parody. The Teachings of Twentieth-Century Art Forms, University of Illinois Press 2000, s. 16; Simon Dentith, Parody, Routledge 2000, s. 9; Margaret A. Rose, Parody: Ancient, Modern and PostModern, Cambridge University Press 1995, s. 46, 51. 
också vad gäller Rönbloms relation till kriminalromanen. De parodiska inslagen växlar i innebörd från uppenbar kritik, exempelvis mot den hårdkokta deckarens avarter, till en hållning som kan sägas rymma såväl sympati som självironi gentemot den genre även författaren ingår i.

Likaledes återfinns hos Rönblom den anknytning mellan parodi och metafiktionalitet som samma teoretiker uppmärksammar. Parodin på en fiktionstext kan tjäna som påminnelse om att alla skönlitterära texter, även den parodierande, är konstruktioner och inte har någon oproblematisk relation till verkligheten. ${ }^{32}$ Linda Hutcheon menar att detektivromanen exemplifierar den självrefererande, metafiktionella litteraturen överhuvudtaget och pekar på tre kännetecken för genren: att den gärna understryker textens fiktiva karaktär genom att låta en av aktörerna vara författare av just kriminalberättelser; att den öppet talar om de konventioner som är förhärskande inom genren; och att läsningen av deckare blir emblematisk för all litteraturläsning genom att tolkningsprocessen är så central. ${ }^{33}$ Rönbloms texter anspelar ofta på kriminalromanens schabloner och dessutom på åtskillig annan skönlitteratur, då på ett sätt som många gånger får en metafiktiv innebörd.

Pipan bidrog, står det i Död bland de döda, till att ge Paul Kennet "en viss detektiv myndighet”. Rönbloms huvudperson har med sina rökpipor Sadrak, Mesak och Abednego, uppkallade efter de tre männen i den brinnande ugnen i Daniels bok, visserligen utrustats med Sherlock Holmes' attribut, men när ortspresen i samma roman öppet jämför honom med hans store föregångare inom genren förstärks ett redan påfallande parodiskt inslag. Kennet skiljer sig uppseendeväckande från hela den linje av färgstarka, självmedvetna och geniala detektiver som följt Conan Doyles hjälte i spåren. Icke desto mindre förses han i debutromanen med en Watson, den doktor Angelbäck som hjälper honom att pröva sina hypoteser och som passande nog själv reflekterar över hur hans funktion erinrar om Holmes' ständiga hjälpreda. Andra inslag refererar på liknande sätt till fiktionsskapelser av olika art. Paul Kennet utger sig vid tillfälle för att själv vara deckarförfattare och diskuterar då fallet som ett uppslag till en kommande bok. Då han första gången konfronteras med pensionatets gäster tänker han: "Utmärkande för dåliga skådespelsförfattare är att de fyller scenen med arbetslösa, med människor som inte har någon uppgift att fylla där men som finns där ändå för att vara till hands i ett senare skede av handlingen”. Hans övervägande att undersöka notarien Odells död följs av tankar kring kriminallitteraturens klichéfigurer:

Detektiver, sådana som Paul Kennet föreställde sig dem, var antingen vassnästa män som snusade morfin eller läppjade på ädla vinsorter och som ur sina länstolars djup löste gåtor med en sinnrikhet av det mest genomborrande slag, eller också var de plattfotade män som bälgade öl och utförde rutinarbete och som med godmodig brutalitet tvang boven att erkänna var han höll det trubbiga föremålet dolt. Ingen av typerna passade riktigt Pauls eget kynne. Han var varken vassnäst analytiker eller plattfotad arbetsträl.

Ytterligare en passage vänder sig mot pusseldeckarens intriger: "Verkliga mordgåtor är sällan så beskaffade att gärningsmannen är att söka inom en strängt sluten krets av människor, vilka kan studeras som fiskarna i ett akvarium. Det är företrädesvis i detektivromaner sådana mordgåtor odlas". Greppet att avgränsa sig mot förment osannolika versioner av genren är

32 Hutcheon, A Theory of Parody, s. 20, 86; Dentith, Parody, s. 84; Rose, Parody, s. 91; Patricia Waugh, Metafiction. The Theory and Practice of Self-Conscious Fiction, Routledge 1996, s. 2.

33 "The act of reading is here an act of interpretation, of following clues to the answer of a given problem. The hermeneutic gaps are textually functional in an explicit manner here, but the process is emblematic of that of reading any novell", Linda Hutcheon, Narcissistic Narrative. The Metafictional Paradox, Methuen 1984, s. 71ff. 
vanligt inom kriminalromanen överhuvudtaget och kan i allmänhet tolkas som ett sätt att hävda den egna textens realism. Men här ingår det i ett större mönster som gång på gång uppmärksammar läsaren på hur texten är formad i ett växelspel med den litterära traditionen. Till saken hör dessutom att Kennet "avsiktligt" lägger sitt mordfall "till rätta för amatörbruk", d.v.s. han rättar sig efter nödvändigheten att inskränka sin undersökning till pensionatets gäster och därmed till just pusseldeckarens mindre krets av misstänkta. ${ }^{34}$

Tekniken är densamma i Höstvind och djupa vatten, där Kennets syster Susanne inträder som en mera uppsluppen Watson-variant, ständigt redo att bistå brodern med vildvuxna idéer hämtade från hennes läsning av Agatha Christie. "Har du bestämt dig för om du vill ha honom till huvudperson i ett svartsjukedrama eller i en spioneriaffär?", frågar Susanne vid tillfälle och förvandlar därmed Kennet till författare snarare än detektiv. Mot systern och hennes beundran för pusseldeckare står en av de misstänkta, som med samma entusiasm anbefaller njutningen av hårdkokta alster med titlar som "Knockout på bruden" eller "Kistan full med bly", den senare "Vålds. upphets. thriller" med nyhetsbladets parodierade förkortningsteknik. ${ }^{35}$ Romanen innehåller också ett exempel på spel-i-spelet, en amatörteaterföreställning refererad med vällustig ironi gentemot det melodrama som uppförs. Den pekoralistiska dialogen tillsammans med berättarens och Paul Kennets kritiska iakttagelser riktar fokus mot texters språkliga karaktär, men har föga samband med den pågående brottsutredningen..$^{36}$ Inslaget kan ses som inspirerat av Shakespeares A Midsummer Night's Dream, det klassiska mönstret för förlöjligande av amatörismen på scen och som dessutom har en framträdande roll i Rönbloms Krans åt den sköna. Holmes-Watson-konstruktionen får för övrigt en särskilt ironisk framtoning i Tala om rep. Den doktor som tycks biträda Kennet och som även denna gång omtalas som en Watson visar sig i själva verket vara mördaren. Avslöjandet innebär samtidigt en tydlig anspelning på Agathas Christies uppmärksammade Dolken från Tunis, där greppet användes första gången. ${ }^{37}$ Spänningen mellan vardaglig realism och parodisk metafiktionalitet drivs till sin spets i Skratta, Pajazzo, där skeendet vid Komosse glasbruk genomgående relateras till konventioner och inslag typiska för framförallt teater och opera. Romanen inleds med vad som ter sig som en rollista från folklustspel av äldre datum: "Kasper Barrman, deras krokryggige betjänt. Mary, hans kärlekskranka nièce. Den tappre kaptenen Karolin. Den upptågslystne glasblåsaren Arklin”. Läsaren påminns också i fortsättningen om personernas sceniska agerande. Handlanden rör sig "som en docka i ett kasperspel", två bybor i handelsboden tar "ett samtidigt steg framåt som i en menuett", Augustin sätter fram ena foten "som när man på operascenen markerar att man överväldigas av känslor", Mary Barrmans mamma har ett ansikte som liknar "en överdriven teatermask" och Viran Albinsson betecknas efter att förhandlingarna kring glasbruket avslutats som "Deus ex machina i byråchefsutförande" (s. 7, 12, 17, 33, 159, 199). Kapitlen har dessutom rubriker som "Prolog i lantlig butik", "Komedianterna samlas på scenen och en faller död ner" och "Epilog i romantisk belysning".

Till detta kommer att kapitlen genomgående inleds med två citat. Ett av dessa är konsekvent taget från operan Pajazzo, varifrån Augustin Lesser hämtat den aria som blev hans karriärs enda succé. Det andra kommer från olika skrifter kring glastillverkningens historia eller, vad gäller

34 Rönblom, Död bland de döda, s. 135, 181, 161, 116, 15, 25, 75.

35 Rönblom, Höstvind och djupa vatten, s. 40, 65, 135, 152, 118, 125.

36 Waugh, Metafiction, s. 15; Hutcheon, Narcissistic Narrative, s.117; Dentith, Parody, s. 131.

37 H.-K. Rönblom, Tala om rep, P.A. Norstedt \& söners förlag, 1958, s. 106, 212; Agatha Christie, Dolken från Tunis

(The Murder of Roger Ackroyd, 1926), övers. M. Isberg, B.Wahlströms bokförlag 1952. 
epilogen, från Hjalmar Gullberg. Redan citatens olikartade karaktär skapar en ironisk kontrastverkan. Under rubriken "Kaptenen försvarar en dam och lantfolket dansar" står först, hämtat från Pajazzo: "I skolen se det bittra hatets frukter, skåda smärtans ryckningar, höra hur vreden ryter", varefter följer "Glasblåsaren stod i högt anseende och adlades i många fall för ådagalagda förtjänster. Löneförmånerna utgjorde daglön (---)äfvensom en hatt med guldträns" (s. 69). Patos ställs mot torr saklighet och ger samtidigt två olika perspektiv på kapitlets innehåll. ${ }^{38}$

Operan Pajazzo, i original I Pagliacci, av Ruggiero Leoncavallo, handlar om ett litet kringresande sällskap av commedia dell'arte-aktörer vars föreställning i en by kompliceras av att ledaren Canio - som skall spela Pajazzo - med rätta misstänker sin hustru Nedda - spelande Colombine - för att ha en kärleksaffär med en av byinvånarna. Verkligheten bryter igenom spelet och föreställningen slutar i tragik, då Canio dödar såväl hustrun som hennes älskare. ${ }^{39}$ Relationen mellan denna text och Rönbloms berättelse ter sig sammansatt. Å ena sidan trivialiseras de stora passioner operan ger uttryck för då de förpassas till Komosses miljö och kärlekshistorierna infogas i klassamhällets villkor. Å andra sidan kan Mary Barrman, som också dödar då hennes förhållande blir hotat, uppfattas som en motsvarighet till Canio. Mordoffret Augustin däremot har vunnit framgång med Canios aria om tvånget att dölja sin sorg inför publiken, men framstår som enbart posör. Han har t.ex. aldrig tagit kamp med familjen för sin kärlek till Viran.

Via det intertextuella förhållandet till Pajazzo understryks också romanens drag av commedia dell' arte. Glasblåsaren Arklin hos Rönblom bär inte bara namnets likhet med Harlekin, utan har dessutom utrustats med rutiga byxor, som direkt påminner om teaterfigurens klädsel, och med dennes fysiska smidighet (s. 35, 123). Han talar också om för Paul Kennet att han hämtar inspiration till sina glasfigurer från just commedia dell'arte. Arklin flickvän Elsie, "ortens skönhet" och anställd på brukskontoret, blir mot denna bakgrund en variant på tjänsteflickan Colombine. Karolin med sin kaptenstitel motsvarar tydligt den uppblåste Capitan som likaledes tillhör de stående rollerna i commedia dell'arte, medan den åldrige Kasper Barrman i första hand bör relateras till kasperteaterns figurer, men också har en viss likhet med olika tjänare i den italienska traditionen. Den inlånade rolluppsättningen kan inte sägas vara konsekvent genomförd av Rönblom, men mönstret från commedia dell'arte ger romantexten en mångtydig dubbelhet bortom det verklighetsillusoriska. ${ }^{40}$

Till de parodiska inslagen i Skratta, Pajazzo måste också räknas Rönbloms förtjusning i falska thrillereffekter. Ett avsnitt avslutas med en typisk s.k. cliffhanger där Kennets syster Susanne ensam och rädd tvingas konfrontera direktören Mackenzie Lesser, vars hotfullhet understryks av att ögonen är "hårda - som på ett kräldjur" (s. 161). Först efter ungefär tio sidor av parallellhandling får läsaren veta att Mackenzies ilska slagit om i faderlig välvilja och spänningen upplösts i en antiklimax (s. 172). Längre fram har Kennet larmat landsfiskalen som har "befogenhet att anhålla folk för mord" (s. 208) och denne är också på väg samtidigt som flera av dramats huvudpersoner äntrar ett tåg för att lämna Komosse. ”En kronans tjänstebil hade kört upp framför stationen och parkerat bredvid direktör Lessers stora vagn. Ur tjänstebilen steg lagens majestät med galoner på kavajärmen. - Landsfiskalen! sade gästgivarn” (s.215). Kapitlet slutar här, och först i nästa står det klart att tåget avgått utan att ordningsmakten ingripit. Även

38 Lewin, Cambridge University Press 1997, s. 300f. Waugh, Metafiction, s. 97, betonar i sin tur hur den här typen av inslag påminner om textens karaktär som språklig skapelse och tjänar metafiktiva syften.

39 Sohlmans opera. 686 operor från La Dafne 1597 till Animalen 1979, Sohlmans 1981. Operalibrettot till I Pagliacci i anonym engelsk översättning har hämtats från http://www.opera-guide.ch/libretto.php?id=194\&uilang=de\&lang=en. 40 Giacomo Oreglia, Commedia dell'arte, Bonniers 1964. Wendelius, Deckarförfattaren H.-K. Rönblom, s. 76ff. 
denna gång förbyts en välannonserad höjdpunkt i intet.

Kriminallitteraturens metafiktiva drag har tilldragit sig intresse inom forskningen, dess parodiska inslag däremot i betydligt mindre grad. ${ }^{41}$ Närmast som ett undantag framstår Sally R. Munt, som i Murder by the Book. Feminism and the Crime Novel hävdar att parodin av en manligt dominerad genre ingick i de kvinnliga deckarförfattarnas strategi alltifrån förra sekelskiftet. Munt uppfattar Agatha Christie som typisk i det avseendet och den föga maskuline Hercule Poirot som exempel på "parody of the male myth". Det kan tilläggas att en Christie-roman som Varför bad de inte Evans? innehåller en hel provkarta på parodiskt-metafiktiva inslag, som tjänar till att påminna läsaren om genrens klichéer. ${ }^{42}$

Samma förtjusning i att omge berättelsens huvudspår med hänvisningar till kriminallitteraturen visar sig hos Dorothy L. Sayers, den föregångare inom genren som H.-K. Rönblom tydligast relaterar sig till. Redan i debuten Lord Peters största affär framträder Sayers detektiv, lord Peter Wimsey, som en halvt parodisk Sherlock Holmes-variant. Flera gånger refererar han explicit till Conan Doyles hjälte eller till detektivromanens konventioner och det sägs dessutom om honom: 'Hans sinne hade snedvridits i ungdomen av 'Raffles' och 'Sherlock Holmes' och de ideal för vilka de står som förebild". ${ }^{43}$

Rönbloms närhet till Sayers kommer till synes dels i mer eller mindre dolda allusioner, dels i sådana drag som är gemensamma för dem båda. Döden i grytan utspelas på en Stockholmstidning, där Paul Kennet får tillfällig anställning för att under falsk flagg kunna lösa en mordgåta och samtidigt ge inblick i en specifik yrkesmiljö, en idé som påfallande överensstämmer med Sayers' Mördande reklam. Denna Rönbloms fjärde roman bär dessutom samma titel som den bok Sayers' kvinnliga huvudperson, Harriet Vane, håller på att skriva i Oskuld och arsenik. Liksom Vane har också en figur hos Rönblom tillhandlat sig gift som ett led i förstudierna till sin planerade deckare och därför blivit misstänkt för ett mord. Sayers’ sätt att presentera detta inköp utsätts å andra sidan för viss ironi i Skratta, Pajazzo: 'I engelska detektivromaner är det lätt att skaffa gift. Man strövar in i en droghandel, uppger sig heta Smith och får genast vad gift man vill ha för att utrota råttor och ogräs med. Svensk lagstiftning på området är långt mindre tillmötesgående mot mördare. De nödgas tillgripa de trubbigaste föremål för att sätta sina planer i verket" (s. 131). ${ }^{44}$

Den försynte adjunkten Kennet kan tyckas fjärran från Sayers’ snarast påfrestande verbale lord Peter, vilken dessutom tecknas som en universell begåvning i Holmes’ efterföljd, en man vars intellektuella skärpa paras med fysiskt mod, social smidighet och dyrbara finkulturella intressen. Dock synes Kennet från Wimsey ha övertagit den sinnets känslighet inför de egna

41 Heta Pyrhönen, Murder from an Academic Angle. An Introduction to the Study of Detective Narrative, Camden House 1994, s. 32ff, 56, 105. Pyrhönens översiktsarbete innehåller ett avsnitt om forskning kring "The SelfReflexivity of Detective Fiction". Studier av relationen mellan parodi och metafiktionalitet beörs dock enbart i förbigående.

42 Sally R. Munt, Murder by the Book? Feminism and Crime Fiction, Routledge 1994, s. 18; Agatha Christie, Varför bad de inte Evans? (Why didn't they ask Evans?, 1934), övers. Einar Thermaenius, Bonniers 1984.

43 Dorothy L. Sayers, Lord Peters största affär (Whose Body?, 1923), övers. N. Edward Werner, B. Wahlströms förlag 1953, s. 215. Greppet återkommer. "Ni förstår, jag leker Sherlock Holmes. Har det som hobby”, yttrar Wimsey i den senare Naturlig död?, där han tillika får hävda att ett mord planerats efter noggrann läsning av R. Austin Freeman, en av dåtidens främsta pusseldeckarförfattare. Dorothy L. Sayers, Naturlig död? (Unnatural Death, 1927), övers. Alvar Zacke, Bonniers 1951, s. 36, 230.

44 Dorothy L. Sayers, Mördande reklam (Murder must Advertise, 1933), Bonniers 1950; Oskuld och arsenik (Strong Poison, 1930), övers. Dagny Hanschen och Ivar Harrie, Bonniers 1947. På liknande sätt förkastas i Rönbloms Död bland de döda, s. 61, Sayers' mordmetod i Naturlig död?, en injektion av luft, som varande alltför otillförlitlig. 
ingripandena, som gör att den senare kan överfallas av djupaste melankoli sedan han avslöjat mördaren. ${ }^{45} \mathrm{I}$ åtminstone några av Sayers' romaner beskrivs också förövarna med den nyansering och förståelse som starkt skiljer sig från t.ex. Christies hållning och som däremot är genomgående hos Rönblom. ${ }^{46}$ Då Rönblom efterhand i sin serie låter ungkarlen Kennet först möta och sedan gifta sig med journalisten Lena Åtvid kan även det ses som att han träder Sayers i spåren. Dennes Oskuld och arsenik brukar uppfattas som ett brott med pusseldeckarens normer, då hon där införde kärleken som ett centralt motiv och fortsättningsvis, fram till den avslutande Lord Peters smekmånad, lät handlingen kretsa inte bara kring brotten utan också kring romansen mellan Harriet Vane och Wimsey. Vanes inträde innebar dessutom att romanerna återkom till den moderna yrkeskvinnans situation som en samhällsfråga. Liksom Sayers’ par kommer även Rönbloms att samarbeta kring fallen i en tvåkönad variant av Holmes-Watsonklichén. De romantiska aspekterna förblir dock nedtonade hos Rönblom.

Inte minst i denna strävan att bredda genrens smala register kunde Rönblom finna stimulans hos Sayers. Av hennes elva kriminalromaner med lord Peter som huvudperson är egentligen bara en renodlad som pusseldeckare. ${ }^{47}$ De övriga varierar mönstret på olika sätt och siktar uppenbart till att tillgodose också andra läsarintressen än dem brottsgåtan erbjuder. Milt satiriska skildringar av sociala miljöer varvas med färgstarka porträtt ur ett typgalleri och med ofta parodiska exempel på klassamhällets många språkarter. Inslagen har sin motsvarighet hos Rönblom, även om hans miljöer och karaktärer genomgående är vardagligare än de som träder Wimsey till mötes.

Sayers’ och Rönbloms flitiga användning av allusioner till och citat från höglitterära texter har blivit viktig för helhetsbilden av deras författarskap och kräver därför en viss utförlighet $\mathrm{i}$ diskussionen. En av Sayers' romaner, Kamratfesten, tilldelas sålunda en nyckelroll i Jim Collins' beskrivning av 1930-talets engelska detektivroman som präglad av "new self-consciousness and desire to evaluate the status of the genre". Enligt Collins arbetar Sayers här "furiously" för att bevisa att detektivberättelsen kan uppnå "the 'highest levels", , bl.a. genom att inleda varje kapitel med citat från Shakespeare och andra klassiker: "the novel (...) appeals to a timeless core within which it attempts to include itself'. ${ }^{48}$

Collins' uppfattning framstår som alltför ensidig. ${ }^{49}$ Tekniken att anknyta till klassiker behöver inte innebära att man placerar sin egen text på samma nivå. Citaten i Kamratfesten skiftar dessutom vad gäller relationen till romanens skeende. Vid sidan av det drag av tidlöshet som uppstår då nutidens mänskliga passioner blir belysta med hjälp av äldre författare, kan man

45 Sayers, Naturlig död?; Lord Peters smekmånad (Busman's Honeymoon, 1937), övers. Sonja Bergvall, Bonniers 1989.

46 Sayers Mördande reklam; Pinsamt intermezzo på Bellonaklubben ( The Unpleasentness at the Bellona Club, 1928), övers. Sonja Bergvall, Bonniers 1951.

47 Dorothy L. Sayers, Fem villospår (Five Red Herrings, 1931), övers. Sonja Bergvall, Bonniers 1944, är helt koncentrerad på undersökningen av en liten grupp misstänkta, inklusive de studier av tågtidtabeller som närmast karikatyrartat kännetecknade engelska detektivromaner under mellankrigstiden.

48 Jim Collins, Uncommon Cultures. Popular Culture and Post-Modernism, Routledge 1989, s. 50f.

49 Sayers ville själv inte göra anspråk på att Kamratfesten som hon betecknade som "rather peculiar" skulle vara ett arbete av stor litterär betydelse. Hon beskrev också romanen som "not really a detective story at all, but a novel with a mild detective interest of an almost entirely psychological kind", The Letters of Dorothy L. Sayers. 18991936: The Making of a Detective Novelist. Chosen and Edited by Barbara Reynolds with a Preface by P.D. James, Hodder \& Stoughton, London 1995, s. 355, 357. 
också spåra ironiska accenter. ${ }^{50}$ Sayers’ förhållande till den s.k. stora litteraturen bedöms överhuvudtaget mera rättvisande då man tar hänsyn till ytterligare två texter. Den tidigare Wimseyromanen Naturlig död? använder också den citat under rubriken till varje kapitel, så t.ex. från Shakespeares Henrik VIII: "Det vore farligt till att grubbla på slika ting för mycket, ty det kunde till ondo fresta -". ${ }^{51}$ Redan namnet Shakespeare tillsammans med den ålderdomliga språkdräkten skapar en mångtydighet i förhållande till de prosaiska ämnen som avhandlas i kapitlet, ofta via en komisk replikföring. Om Sayers kan tänkas vilja höja genrens prestige med hjälp av citatet, så gör hon det samtidigt på ett sätt som snarast vittnar om den respektlöshet lärdomen ibland kan tillåta sig. Ett liknande intryck ger också det föredrag, ”Aristotle on Detective Fiction”, som hon höll i Oxford 1935, samma år som Kamratfesten utkom, och där hon försvarar detektivromanens idé med hänvisning till Aristoteles, som i djupet av sitt hjärta sägs ha längtat efter "a good detective story". ${ }^{52}$

Magnus Persson har i sin Kampen om högt och lågt i hög grad utgått från Collins' bild att den engelska pusseldeckaren kännetecknades av en "alltmer intensifierad strävan efter litterär legitimitet" och ser 50-talets svenska kriminalroman i samma perspektiv. Rönblom får då illustrera en entydigt pretentiös hållning via en formulering i Död bland de döda där Kennets tre pipor sägs likna "tes, antites och syntes i ett hegelskt schema". ${ }^{53}$ Man kan också här - liksom ifråga om Sayers - se ett närmast parodiskt utnyttjande av lärdomsgods, en teknik som naturligtvis förutsätter vissa kunskaper hos läsarna men som inte kan reduceras till att enbart handla om att skänka kulturell polityr åt deckargenren.

Rönbloms tidigare romaner förser genomgående kapitlen med inledande citat. Variationen är samtidigt påfallande. I Skratta, Pajazzo handlar det, som sagt, om ett kontrastspel mellan olika typer av texter. Tala om rep använder fiktiva citat av samma sorts komiska pekoralpastisch som Birger Sjöberg och Nils Hasselskog har odlat. I Död bland de döda återges enstaka rader från den etablerade svenska lyriken, dock utan författarnamn. Höstvind och djupa vatten utnyttjar genomgående texter av Hjalmar Gullberg, Döden i grytan av Bo Bergman. Poeterna Gullberg och Bergman, båda förtjusta i ironiska stilbrytningar och med fokus på vardagligt liv, har åtskilliga drag gemensamma med Rönblom och kan dessutom sägas förstärka romanernas tyngre stråk, det allvar som ändå träder fram i skildringen av våldsdåd och mänskliga felsteg. Samtidigt ryms även här en lekfullhet som Lars Wendelius har poängterat. ${ }^{54}$ Man kan se ett exempel då ett citat från Bergman - "och elden som mitt inre tär är inte bara lusteld heller" får inleda ett utomordentligt uppsluppet kapitel kring en hårdsupande grönländsk poet. ${ }^{55}$ Även dessa inslag kan sägas tillhöra det spel med texter av skiftande art som Rönblom underhåller

50 Se t.ex. hur Robert Burtons ord om "a monastical College for old, decayed, deformed or discontented maids to live together in" ger en ironisk accent åt romanens bild av det kvinnliga college som står i centrum. Sayers, Gaudy Night (1936), Chivers Press 1988, s. 125. Citaten saknas i den svenska upplagan Kamratfesten, övers. Sonja Bergvall, Bonniers 1989.

51 Sayers, Naturlig död?, s. 145.

52 Dorothy L. Sayers, "Aristotle on Detective Fiction. Lecture Delivered at Oxford, March $5^{\text {th }}$ 1935, Unpopular Opinions, Victor Gollancz 1946, s. $178 \mathrm{ff}$.

53 Lang, Rönblom och Kerstin Ekman får ge prov på hur referenser till högkultur skulle fungera statushöjande, samtidigt som Persson vad gäller Ekman vill nyansera genom att tala om "ironisk distans" och "ambivalens". Magnus Persson, Kampen om högt och lågt. Studier i den sena nittonhundratalsromanens förhållande till masskulturen och moderniteten, Symposion 2002, s. $189 \mathrm{ff}$.

54 Wendelius, Deckarförfattaren H.-K. Rönblom, s. 70f.

55 Rönblom, Döden i grytan, s. 97ff. 
och där allusionerna till kriminallitteratur också ingår. Generellt bryter de koncentrationen på skeendet och den förmenta neutraliteten i det språkliga uttrycket. Istället framträder en mångfald av språkarter och litterära former.

Man kan i Skratta, Pajazzo finna en betraktelse över skapandets olika nivåer, då Paul Kennet inför glasblåsaren Arklins anspråksfulla idéer om sin skulptur menar att "konst är inte bara övning och fingerfärdighet utan också ande" (s. 120). En liknande hållning återkommer i en artikel av Rönblom från 1955, där han skriver, att detektivromanen är "ett nervgift, ett lättillgängligt preparat med 'makten att hålla förtvivlan tillbaka'. Självklart äger ett sådant nervmedel inte den helbrägdagörande verkan som den stora litteraturen har - den som är andens mat och dryck, medan detektivromanen är andens tabletter och pulver". ${ }^{56}$ Artikeln ger ytterligare prov på Rönbloms opretentiösa och traditionstrogna inställning till den egna genren, men också hans lätt ironiska umgänge med litteraturens klassiker.

Jim Collins' och Magnus Perssons uppfattning om en genre som framförallt siktar till erkännande och kulturell status förblir träffande vad gäller vissa författare, men bör nyanseras genom att man istället betonar t.ex. Sayers’ och Rönbloms mångtydiga, på en gång kärleksfulla och distanserade förhållande till sitt hantverk. ${ }^{57}$ De parodiska och metafiktiva inslagen understryker då en medvetenhet om genrens begränsningar men också hur texten kan ses som ett roande spel, reglerat av starka konventioner. Icke desto mindre kan samma författare bryta mot nedärvda mönster och förena sin traditionalism med inslag som närmar kriminalromanen till frågor aktuella i samtiden.

\section{4}

Rönblom formar sin i övrigt försynte romanhjälte Paul Kennet till ett mönster av orädd självständighet och sanningssträvan, till synes väl i samklang med författarens egna liberala ideal. Förvisso anges en blandning av motiv bakom Kennets ingripanden, men framförallt representerar han den enskildes nödvändiga ansvarstagande i samhället. Hans undersökningar möter också motstånd eller uppfattas som skandalösa av en omgivning som fruktar att deras intressen skall komma till skada. I Död bland de döda blir han närmast en social paria för pensionatets ägare och gäster då han inte vill acceptera Odells frånfälle som resultatet av sjukdom. På liknande sätt hotar familjen Lesser i Skratta, Pajazzo att stämma honom då han envisas med att misstänka ett övergrepp bakom Augustins död. Egenartat nog intar adjunkten en roll som påminner om de hårdkokta amerikanska deckarnas yvigare hjältar - en ensam man som utan hänsyn till konsekvenserna vågar stå upp för sanningen gentemot samhällets mäktiga.

Detektivens oppositionella läggning blir tydligt åskådliggjord i Tala om rep där han i konfrontation med "en överhetsperson i maktutövning", i det här fallet landsfiskalen, tänder en av sina tre pipor som var "uppkallade efter män som missuppfattat sin ställning i samhället och som därför satts i en brinnande ugn för att återföras till ordningen" ${ }^{58}$ Landsfiskalen har här smugglat undan några brev från platsen för ett dödsfall och på så sätt velat skona en kvinna ur den lokala eliten. Då han accepterat Kennets slutsatser kring den döde rättar han emellertid

56 H.-K. Rönblom, "Endast för segervissa", i Meningar om mord. 15 uppsatser om deckare, deckarförfattare och deckarhjältar, red. Jan Broberg, Cavefors 1968, s. 21.

57 Som Persson skriver ter sig t.ex. Maria Lang ofta uppseendeväckande angelägen att förse figurerna i sina brottshistorier med "karaktärsegenskaper som skall konnotera bildning och högkultur". Persson, Kampen om högt och lågt, s. 190.

58 Rönblom, Tala om rep, s. 11. 
sitt misstag och den grava korruption romanen låter ana förvandlas till ett tillfälligt felsteg, samtidigt ett symptomatiskt resultat av det sociala spelet. Polismakten beskrivs överhuvudtaget relativt välvilligt av Rönblom, som en myndighet som kan bistå Kennet och förse honom med information, men det är i slutänden ändå amatören som löser problemen, inte som hos rivalerna på den svenska deckarmarknaden kommissarierna Vesper Johnson, Christer Wijk eller O.P. Nilsson. Greppet kan helt enkelt synas tillmötesgå pusseldeckarens konventioner, dess hyllning av den begåvade privatdetektiven på de tungfotade polismännens bekostnad, men går dessutom att tolka som ett uttryck för misstro mot ett samhälle där inte heller polisen tycks kunna garantera rättvisan.

Mot Kennet står också i flera romaner folkliga kollektiv som inger föga förtroende för demokratins krafter. I Senatorn kommer tillbaka blir detektiven t.o.m. inblandad i slagsmål då han vill skydda en ung man mot den byopinion som förvandlas till en rasistisk lynchmobb. I Skratta, Pajazzo ter sig ortsinvånarna i Komosse löjeväckande okunniga och oförmögna att höja sig över sitt kråkvinkelperspektiv. Vid ett möte kring byns framtid i skolhuset ställs Viran Albinssons till synes något naiva men välmenta idéer om en reformerad ungdomsvård mot bybornas fördomsfulla motstånd. Den lokala demokrati som här avbildas slutar karaktäristiskt nog i kaos. Virans avfärd med tåget sedan en uppgörelse skett ger till sist tillfälle till ytterligare satir. "Hela Komosse” som nu vill bringa "avresande styrelse och överhet en kort och hjärtlig hyllning" ger omväxlande ifrån sig "läten av allmän välvilja" och instämmer i de leven som utbringas av den bölande brukssmeden (s. 209ff).

Lars Wendelius talar å ena sidan om den "leda vid nuet och den nostalgiska längtan till det förflutna som ibland kommer till uttryck i Rönbloms böcker", å den andra om "en harmonisk sammansmältning" mellan det numedvetna och det nostalgiska. ${ }^{59}$ Det ter sig emellertid svårt att någonstans finna någon längtan till det förgångna hos Rönblom. Paul Kennets gamla svärmor, fru Åtvid, som Wendelius tar som exempel, representerar visserligen ett förflutet som sägs fängsla och charmera historikern, men framförallt en vishet av synnerligen illusionslöst slag. Den överklassiga känsla för "stil" från äldre tider hon talar om är i hennes ögon skild från all moral. ${ }^{60}$ De orter som lever på skuggsidan av moderniteten kan heller inte förknippas med nostalgi. Ett samhälle som Komosse framställs som format av de hårda klassgränser, som ännu i nutiden sätter spår hos såväl ägarfamiljen som byinvånarna. I Bok över obefintliga beskrivs inledningsvis en liten ort i ordalag som antyder ett närmast organiskt sammanhang mellan bebyggelse och natur - "Linåker verkade ha varit med redan när skogsbrynet anlades" - men efterhand tröttnar Kennet på "anblicken av den orkeslösa byn” och tycker sig se hur de kvarvarande invånarna "sitter kvar och mumifieras i hopplös förnöjsamhet". ${ }^{11}$ Skildringen av hämmande instängdhet i romanerna når en kulmen med sista sidan i Krans åt den sköna, där Kennets hustru Lena förkunnar sin avsky för Tegelvik, "den här otäcka lilla hålan". ${ }^{62}$

Lika litet står nutiden för något positivt alternativ hos Rönblom. Det går t.ex. knappast att i Skratta, Pajazzo utläsa någon tillfredsställelse med hur Komosses framtid avgörs i det satiriskt återgivna spelet mellan stat, kapital och fackförening och hur menigheten i efterhand applåde-

59 Wendelius, Deckarförfattaren H.-K. Rönblom, s. 35, 43. Sara Kärrholm instämmer i Wendelius' analys. Se Kärrholm, Konsten att lägga pussel. Deckaren och besvärjandet av ondskan i folkhemmet, Symposion 2005, s. 199.

60 Rönblom, Tala om rep, s. 121f.

61 Rönblom, Bok över obefintliga, s. 26, 151.

62 Rönblom, Krans åt den sköna, s. 212. 
rar. ${ }^{63}$ Vad som skildras är snarare hur nödvändigheten dikterar villkoren och hur, typiskt nog, uppgörelsen blir en seger för Mackenzie Lesser och Karolin, styckets två mest osympatiska figurer. Arklins idé att istället satsa på konstglastillverkning framstår samtidigt som föga verklighetsanpassad. Överhuvudtaget ger Rönbloms exposéer över romanernas småsamhällen aldrig uttryck för någon framtidstro. Även då han tillåter sig en relativt ljus beskrivning av den lilla ort Kennet besöker i Död bland de döda, registrerar ironin en tilltagande konformitet: "i dess innersta och äldsta del skockade sig husen fortfarande i glad oordning, målade i var sin särskilda kulör, men utomkring bildade de räta vinklar med varandra och var rappade i en gulaktig färg av socialt utseende". ${ }^{64}$ Stockholm, modernitetens centrum, är arenan i två av böckerna, men skildras i den ena främst via det perspektiv som ges från de försvinnande Klara-kvarteren, i den andra som en tummelplats för narkotikaligor. ${ }^{65}$

Hos Rönblom finns inget av Trenters medelklassoptimism, Langs föreställning om en harmonisk samhällsgemenskap, eller den folkhemstrygghet polisen O.P. Nilsson får representera hos Suneson. Tilltron till den enskildes rättsinne och oväld, förkroppsligad i Paul Kennets gestalt, ställs mot en samhällsmekanik som befordrar elitstyre, nedtystande och lösningar opåverkade av en folklig delaktighet - som f.ö. heller inte tillmäts någon positiv kapacitet. Det är en bild som i första hand tycks präglad av de svenska krigsårens ogenomskinliga överhetsstyre och av rättsrötedebatterna i 50-talets början. Den blir än mer accentuerad genom en form av determinism som ser människorna som alltigenom styrda av personliga karaktärsdrag, av kollektivets makt eller framförallt av de sociala roller de tilldelats av samhällsmönstret. Vid flera tillfällen anknyter Rönblom till Bo Bergmans dikt "Marionetterna". Upplösningen i debutromanen Död bland de döda följs av ett citat - "Vi stackars marionetter" - som ytterligare förstärker Kennets sammanfattning av fallet. Mördaren beskriver han som "en fattig lärarinna som sett bättre dagar" och han utmanar den som inte i likhet med henne skulle ha frestats till brott att kasta första stenen. Kennets självkritik signalerar att också hans egna insatser som detektiv hör till de ironiskt "lustiga piruetter" Bo Bergman talar om i sin dikt. På motsvarande sätt inleds ett kapitel i Döden grytan, där Kennet likaså har anledning till självrannsakan, med ett annat citat från "Marionetterna" - "Är bara ryck på trådar". ${ }^{66}$ I Skratta, Pajazzo beskrivs i slutfasen hur Mackenzie Lesser och Karolin, de två män som ter sig skyldigare än mörderskan Mary Barrman, rör sig "ryckigt och stelt likt dockor som förs med snören" (s. 227). Som en variant kan man se hur Rönblom i Höstvind och djupa vatten formar sin berättelse efter mönster från den antika ödestragedin, något som Wendelius utförligt analyserat. ${ }^{67}$ Även i detta fall framstår människan som försvarslös mot makter bortom hennes kontroll.

Att skeendet här får ett drag av tidlöshet hindrar inte att man också kan spåra en upplevelse av den samtid som händelserna är knutna till. Determinismen ter sig då som ett ytterst radikalt avsteg från Rönbloms liberala ideologi och den tro på individen som där står i centrum. Möjligen finner vi en förklaring i de dystra erfarenheterna från de totalitära diktaturerna och vad de avslöjat om samhällets förmåga att forma den enskilda människan och beröva henne möjligheten att

63 Jag skiljer mig här från Sara Kärrholm, som menar att uppgörelsen "framställs som en god kompromisslösning".

Kärrholm, Konsten att lägga pussel, s. 204.

64 Rönblom, Död bland de döda, s. 40.

65 Jag avser Rönblom, Döden i grytan, respektive Död men obegråten.

66 Rönblom, Död bland de döda, s. 231, 233, 238; Döden i grytan, s. 38. Bo Bergman, "Marionetterna”, Samlade dikter, Bonniers 1941, s. 13

67 Wendelius, Deckarförfattaren H.-K. Rönblom, s. 85ff. 
välja det rätta. ${ }^{68}$ Karaktären Paul Kennet framstår då antingen som illusorisk, hemmahörande enbart i fiktionens värld, eller i ljuset av vad Rönblom själv betonade i sin ovan citerade artikel - som ett exempel på detektivromanens förmåga att "hålla förtvivlan tillbaka", att bekämpa resignationen med litteraturens hjälp. Kännetecknande nog avslutar Rönblom samma artikel med att hänvisa till människorna i London som under bombanfallen 1940 läste idel detektivromaner i sina skyddsrum, övertygade om att "demokratin skulle vinna sitt krig mot diktaturen, att rättvisans handhavare i världen skulle segra och boven skulle gå åt". ${ }^{69}$

\section{Källor}

\section{Analyserad litteratur}

Död bland de döda (1954), Vingförlaget 1956.

Höstvind och djupa vatten (1955), Bra Böcker 1976.

Skratta, Pajazzo (1956), Vingförlaget 1959.

Döden i grytan (1957), Vingförlaget 1959.

Tala om rep, P.A. Norstedt \& Söner 1958.

Senatorn kommer tillbaka (1959), Vingförlaget 1961.

Krans åt den sköna, P.A. Norstedt \& Söner 1960.

Död men obegråten (1961), Vingförlaget 1964.

Bok över obefintliga, P.A. Norstedt \& Söner 1962.

Mannen som höll sig undan, Norstedts 1964.

\section{Citerad och refererad litteratur}

Auerbach, Erich, Mimesis. Verklighetsframställningen i den västerländska litteraturen

(Mimesis. Dargestellte Wirklichkeit in der abendländischen Literatur, 1946), övers.

Ulrika Wallenström, Bonniers 1998.

Bergman, Bo, Samlade dikter, Bonniers 1941.

Blom, Karl Arne, "Appendix", i Julian Symons, Lilla mordboken. Från detektivhistoria till kriminalroman - en historik (Bloody Murder, 1972), övers. Sune Karlsson,

Berghs förlag 1979.

Christie, Agatha, Dolken från Tunis (The Murder of Roger Ackroyd, 1926), övers. M. Isberg, B.Wahlströms bokförlag 1952.

Christie, Agatha, Mordet på Orientexpressen (Murder on the Orient Express, 1934), övers. M. Isberg, Bonniers 1953.

Christie, Agatha, Varför bad de inte Evans? (Why didn't they ask Evans?, 1934), övers. Einar Thermaenius, Bonniers 1984.

Collins, Jim, Uncommon Cultures. Popular Culture and Post-Modernism, Routledge 1989.

Dentith, Simon, Parody, Routledge 2000.

68 I mera begränsad omfattning exemplifierar också socialdemokratins och folkhemspolitikens seger samma växande samhällsmakt. Jonas Frykman och Orvar Löfgren har beskrivit det svenska 30-talets brytningsskede som "individens samhälleliggörande" och hur dessa processer av kritikerna uppfattades som en dramatiskt krympande frihet för den enskilde. Jonas Frykman och Orvar Löfgren, "På väg - bilder av kultur och klass", i Modärna tider. Vision och vardag i folkhemmet, red. Frykman och Löfgren, Liber 1985, s. 137f.

69 Rönblom, "Endast för segervissa", s. 27. 
Frykman, Jonas och Löfgren, Orvar, "På väg - bilder av kultur och klass", i Modärna tider. Vision och vardag i folkhemmet, red. Frykman och Löfgren, Liber 1985.

Genette, Gerard, Paratexts. Thresholds of Interpretation (Seuils, 1987), transl. Jane E. Lewin, Cambridge University Press 1997.

Grant, Damian, Realism, Methuan 1970.

Hamon, Philippe, "On the Major Features of Realist Discourse", i Realism, ed. Lilian R. Furst, Longman 1995.

Hutcheon, Linda, A Theory of Parody. The Teachings of Twentieth-Century Art Forms, University of Illinois Press 2000.

Hutcheon, Linda, Narcissistic Narrative. The Metafictional Paradox, Methuen 1984.

Knight, Stephen, Form and Ideology in Crime Fiction, McMillan 1980.

Kärrholm, Sara, Konsten att lägga pussel. Deckaren och besvärjandet av ondskan i folkhemmet, Symposion 2005.

The Letters of Dorothy L. Sayers. 1899-1936: The Making of a Detective Novelist. Chosen and Edited by Barbara Reynolds with a Preface by P.D. James, Hodder \& Stoughton, London 1995.

Malmström, Sten, Stil och vers i svensk 1900-talspoesi, Norstedts 1971.

Miller, D.A., The Novel and the Police, University of California Press 1988.

Munt, Sally R., Murder by the Book? Feminism and Crime Fiction, Routledge 1994.

Morris, Pam, Realism, Routledge 2005.

Oreglia, Giacomo, Commedia dell'arte, Bonniers 1964.

Palmer, Jerry, Thrillers: Genesis and Structure of a Popular Genre, Edward Arnold 1978.

Persson, Magnus, Kampen om högt och lågt. Studier i den sena nittonhundratalsromanens förhållande till masskulturen och moderniteten, Symposion 2002.

Porter, Dennis, The Pursuit of Crime. Art and Ideology in Detective Fiction, Yale University Press 1981.

Pettersson, Anders, Realism som terminologiskt problem. Några definitioner i modern litteraturvetenskap och deras giltighet, Liber 1975.

Pyrhönen, Heta, Murder from an Academic Angle. An Introduction to the Study of Detective Narrative, Camden House 1994.

Rose, Margaret A., Parody: Ancient, Modern and Post-Modern, Cambridge University Press 1995. Rönblom, H.-K., 'Endast för segervissa", i Meningar om mord. 15 uppsatser om deckare, deckarförfattare och deckarhjältar, red. Jan Broberg, Cavefors 1968.

Sayers, Dorothy L., Gaudy Night (1936), Chivers Press 1988.

Sayers, Dorothy L., Fem villospår (Five Red Herrings, 1931), övers. Sonja Bergvall, Bonniers 1944.

Sayers, Dorothy L., Kamratfesten (Gaudy Night ,1936), övers. Sonja Bergvall, Bonniers 1989.

Sayers, Dorothy L., Lord Peters smekmånad (Busman's Honeymoon, 1937), övers. Sonja Bergvall, Bonniers 1989.

Sayers, Dorothy L., Lord Peters största affär ( Whose Body?, 1923), övers. N. Edward Werner, B. Wahlströms förlag 1954.

Sayers, Dorothy L., Mördande reklam (Murder must Advertise, 1933), Bonniers 1950. 